\title{
Preface
}

\section{Bitter Sugar's Island}

\section{器次}

"But we can't go in," Chacko explained, "because we've been locked out. And when we look in through the windows, all we see are shadows. And when we try and listen, all we hear is a whispering. And we cannot understand the whispering, because our minds have been invaded by a war. A war that we have won and lost. The very worst sort of war. A war that captures dreams and re-dreams them. A war that has made us adore our conquerors and despise ourselves.

"We're Prisoners of War," Chacko said. "Our dreams have been doctored. We belong nowhere. We sail unanchored on troubled seas. We may never be allowed ashore. Our sorrows will never be sad enough. Our joys never happy enough. Our dreams never big enough. Our lives never important enough. To matter."

Arundhati Roy, The God of Small Things

This book is about the political history of my country, Réunion Island, and about emancipatory discourses developed there, about their power to shape reality, the possibilities they offered to, and the limits they imposed on, the population of a small island in the Indian Ocean. As the island's political history has been, since the 1930s, intimately tied to the history of my family, this book is also about members of my family. I do not underestimate the difficulty 
of retrieving the history of present times, when memory and history are deeply entangled. I play with what a French historian has called "human flesh," and I recognize that the stakes are still high. There is always the temptation to offer an anachronistic or embellished representation of the events. On which testimonies, which documents, which archives, do I rest my argument? How do I choose among archival sources? What do the exclusions that I perform say about the text's archaeological selection? I could not entirely avoid being ideologically involved, because traces of colonialism remain and my country is still dependent on France. My sympathies are clear. I side with the anticolonialists in Réunion, with those who have tried for decades to transform a political and economic situation of dependence. There is a high risk of producing a text that ends up being a plea, an apology, or an accusation rather than an explanation. It is a risk that I have consciously taken.

In the last decade, re-visions of the colonial and imperial project have shown that the study of a micropolitical colonial phenomenon can shed light on the complex mechanisms of the colonial relation. On the one hand, such a study insists on the singularity of each colonial experience; on the other, it allows analogies, comparisons, contrasts with other colonial experiences. We who come from our planet's smallest countries, where people had "no Industrial Revolution, no revolution of any kind, no Age of Anything, no world wars, no decades of turbulence balanced by decades of calm," may be said to "suffer from the traumata of insignificance." ${ }^{2}$ As the Mauritian thinker Françoise Lionnet put it, insular "minorities" can "never be tempted by the illusions of leadership, never be deluded into thinking that we can represent anyone but ourselves." Our joys will never be happy enough. Our dreams never big enough. Our lives never important enough. To matter.

Studies of French colonialism have paid little attention to the small islands of the French first colonial empire. They do not seem to offer a site of historical and political investigations that would add to postcolonial theory. ${ }^{4}$ Yet within postcolonial investigations, the "power of historical locality becomes particularly persuasive," Homi Bhabha has written, "as the problem of cultural identity is staged in the discourse of geographical complexity-migration, diaspora, postcoloniality." 5 The history of Réunion (a colony) is part of the history of France (the empire). Geographically distanced but politically integrated, Réunion Island offers a specific site of re- 
search: it is a constituted minority within the nation France but is situated at the periphery; a mercenary minority to its neighbors (independent states that have to confront the West and global capitalism), for it is France's watchdog; a European territory (as a French department, Réunion belongs to the European Economic Community) in an African-Asian environment. What does the political history of emancipation in Réunion bring to postcolonial studies?

My country, Réunion Island, is a small island, formerly a colony on the margins of the French empire and now a French overseas department, a status the island acquired in 1946 along with the French Antilles and French Guiana. ${ }^{6}$ These islands of sugar, which used to be known as the Vieilles Colonies (Old Colonies), ${ }^{7}$ have been the "repressed" of French colonialism, territories that had not been conquered militarily, where there had been slavery, and that did not belong to the great narrative of the mission civilisatrice. Their demand for political assimilation rather than independence has generally situated them outside of the great narrative of decolonization. ${ }^{8}$ It is from this position of "irrelevance" that I speak.

The formation of Réunion's society was literally the creation of a colonial act. ${ }^{9}$ In 1642 the Compagnie Française de l'Orient took possession of the islands of the Mascarene archipelago in the name of the king of France. There were no inhabitants on Réunion when it was colonized. None. No native population massacred, no military conquest, no heroic battles and defeats, but settlement, colonization, slavery, and colonialism. ${ }^{10}$ In 1674 governor Jacob De La Haye wrote the first law that sought to prohibit métissage, which was perceived as leading to degeneration and lack of discipline. ${ }^{11}$

There was slavery on the island at the end of the seventeenth century. ${ }^{12}$ In December 1723 the French state published the Code Noir, a series of prescriptions regulating the slave's life. ${ }^{13}$ Slaves, who, in the first years of colonization, had been bought in India, were now bought in Madagascar and Africa. ${ }^{14}$ Sugar deeply transformed the island's social and cultural order. The plantation became the crucible of "creolization," the process whereby individuals of different cultures, languages, and religions were thrown together and invented a new language, Creole, a new culture, and a new social organization. Sugar also affected the pattern of land ownership. Poor white farmers lost their lands to wealthier landowners and were pushed inland. The existence of an important 
group of poor whites affected the ways in which race ${ }^{15}$ and class interacted.

Slavery was abolished in 1848 . But the plantation system in Réunion expanded even more after the abolition of slavery, affecting the class and racial distribution of the society differently than it did in the French Antilles. In Réunion, the great demand for a cheap workforce after the emancipation of the slaves led the landowners to look to a large diversity of sources for their workforce. ${ }^{16}$ Indentured workers were sought in India, ${ }^{17}$ Malaysia, China, Madagascar, and Africa. ${ }^{18}$ Different religious beliefs (Tamil, Muslim, Christian, Buddhist, animist), languages, cultures, and traditions were put into contact in a small space. In the 1930s, a coalition of workers and republicans demanded the end of Réunion's colonial status and the assimilation of the island into the French republic. Their discourse mixed republican ideals with working-class politics, articulating anticolonialism with workers' rights. The island became a French overseas department on March 19, 1946.

Sugar, bitter sugar, has shaped Réunion's class formation, and we live with its legacy. ${ }^{19}$ Today members of the wealthy white Creole families, descendants of landowners and factory owners, hold important positions in banking and commerce. Among the descendants of Indians, Muslims, and Chinese workers, some families have reached middle-class status and entered political life. The development of the civil service in the 1960s has facilitated the emergence of an important petite bourgeoisie, who earn, thanks to a colonial law still in effect, greater salaries and pay fewer taxes than civil servants in the metropole. The majority of the populationsharecroppers, tenant farmers, unemployed, skilled and unskilled workers, domestics, employees in the private sector-live on the margins of the postcolonial society. They are the descendants of slaves and poor whites. In the last decades, Réunion has been transformed into a "window" of French capitalism. Consumer goods imported from the metropole and the European Economic Community, commercial malls, cellular phones, all the gadgets of postmodern life, have given to the island the look of a French suburb in the tropics. The artificial wealth exhibits the schizophrenic character of a peculiar postcoloniality: the recolonization of a postcolony. ${ }^{20}$ It feeds a certain French colonial nostalgia. It supports the fantasy that somewhere colonization has succeeded, 
blending peoples from diverse cultures under the paternalistic control of French republicanism.

The paradox has been that the 1946 law brought more French people to the island than ever before. French civil servants have imported their ways of living and their idealization of European "modernization." They have conveyed with them the metropolitan conviction that colonialism ended with the Algerian War and that racism has not been intimately connected with the empire and French national identity. As French metropolitans hold the majority of higher-rank functions in the administration, the judicial system, and the university and schools, they have been intent on imposing their ideology. Réunion Island, which belongs to the Indian Ocean Rim, is thus in the paradoxical position of being an appendage of a European country in an African-Asian region, running the risk of becoming an obsolete archaism. Resistance to the recolonization of the island has taken new cultural and political forms: affirmation of Creole as a language, rejection of the ways of living of zoreils (the name given to French metropolitans), and the desire for a greater cultural, political, and economic integration with the countries of the Indian Ocean Rim.

To a certain extent, these facts about Réunion's history are, as Edouard Glissant has noted for Martinique, deceptive. I look at the processes through which the Réunionnais constituted, and are still in the process of constituting, their Creoleness. In Réunion, there is no lost community to retrieve. Our "imagined community" is still in formation.

There is another genesis to this research, which partly explains its orientation. It started in March 1986. The United States was celebrating the bicentennial of Ellis Island with a big party in the harbor of New York and the renovation of the Statue of Liberty and Ellis Island. Magazines such as Newsweek and Time were telling the saga of millions of European families who had come through Ellis Island to live the "American Dream." On the other side of the country, at the border between California and Mexico, between the First World and the Third World, there was another kind of "Ellis Island," the U.S. consulate at Tijuana, Baja California.

In Southern California, the border with Mexico was becoming the last "wall" against the "invasion of illegal aliens," the protective 
barrier of a wealthy, white, healthy, educated group against a poor, brown, unhealthy, uneducated group. The frontera was entering political rhetoric, foreshadowing the debate of the I99os about the meaning of citizenship in the country. The U.S. consulate at Tijuana was one of the sites where the battle to contain the "invading hordes" was taking place. The collapse of the Mexican economy, the civil wars waged by governments against their own peoples in El Salvador and Guatemala led people toward Tijuana, toward El Norte.

That year, 1986, I lived in Rosarito, a Mexican village on the coast some miles south of Tijuana. I was waiting for my entry papers to be processed, to enter the United States of America as a "legal immigrant." Although I was protected by my European passport and by the knowledge that if I failed to obtain a visa, I would not have to return to a country devastated by war, my life threatened by death squads, without the hope of a job, I was, as any person waiting is, subjected to the small humiliations that go everywhere in the world with being allowed by a state to enter its territory. ${ }^{21}$ These small humiliations are intimately part of the immigration process. They are not aberrations, consequences of the employees' moods or even racism (though these aspects play a role). They constitute the immigration process. They consist in letting one believe that all the papers are finally in hand and announcing at the end of the day that one must come back; of asking women candidates for immigrant status to undress during the medical visit and to wear flimsy paper dresses while waiting to be examined by a male doctor. One waits for hours, hoping, lying, dissimulating, sharing happy endings or crushing refusals to the demands. Families sleep outside the consulate to be the first in line. They have a look of enduring patience, the patience of the dispossessed.

Between visits at the consulate, I read. I read while watching the whales going back to the northern waters of America, watching Mexican families having big picnics on the Rosarito beach, watching every weekend the young gringos and gringas getting drunk on margaritas. And that year, as I waited for the next appointment at the U.S. consulate, among the many books I read was one by Michael Paul Rogin, Fathers and Children: Andrew Jackson and the Subjugation of the American Indian. I recognized in the book what I thought historical political analysis should be. The book remained 
to me a model of research. My days in Rosarito were shaped by my reading of Rogin's analysis of how "America clearly began not with primal innocence and consent but with acts of force and fraud." The words were echoes of the paranoid discourse about the border with Mexico, the patronizing attitude of the consulate officers, and the arrogance of the bicentennial celebration. But these words also spoke of resistance, the possibility of critique and radical politics. I entered the United States on Bastille Day of 1986. In 1989 I was accepted into the Ph.D. program of the Political Science Department at the University of California at Berkeley, and Professor Rogin agreed to be chair of my dissertation committee. From Réunion to Algiers to Paris to Rosarito and Berkeley, I finally found the distance and a sufficiently foreign language to speak of the political history of my country. I also found the intellectual environment that made it possible. 
